\title{
SELECTIONS FROM ERIC
}

\author{
Journal Articles
}

EJ 524840

McConnell, Bruce W. (1996, May - June). New Wine in Old Wineskins: U.S. Government Information in a Networked World. Journal of Government Information, v23 n3 p217225. (Available UMI)

Electronic information transforms relationships among the elements of traditional publishing, creating new opportunities and new challenges, especially for the sustainability of information. Anew model of information ecology suggests that current government information dissemination institutions and practices must transform themselves if access to public information is to be maintained and expanded.

\section{EJ 518341}

Sharp, Diana. (1996, January - February). Partnering with Electronic Books and Literature. Media \& Methods, v32 n3 p24-25.

Provides suggestions for combining electronic books with traditional printed materials in a school literacy program. Discusses introducing the printed version of the story to students, having students read this version to others, and encouraging student-produced CD-ROM presentations. A sidebar presents a list of electronic book publishers.

\section{EJ 505431}

Lancaster, F. W. (1995, Spring). The Evolution of Electronic Publishing. Library Trends, v43 n4 p518-527.

Discusses the evolution of electronic publishing from the early 1960 s when computers were used merely to produce conventional printed products to the present move toward networked scholarly publishing. Highlights include library development, periodicals on the Internet, online journals versus paper joumals, problems, and the future of disseminating academic research results.

\section{EJ 523221}

Machovec, George S., Ed. (1996, April). Electronic Journals: Trends in World Wide Web (WWW) Internet Access. Online Libraries and Microcomputers, v14 n4 p1-6.
Examines issues surrounding the publication of electronic joumals and describes publisher solutions to these issues. Topics include pricing, security, electronic page layout, copyright, backfile availability, and reliability and accessibility of data. Describes some electronic joumal projects and lists electronic journal services available via World Wide Web access.

EJ 528068

MacEwan, Bonnie; Geffner, Mira. (1996). The Committee on Institutional Cooperation Electronic Journals Collection (CIC-EJC): A New Model for Library Management of Scholarly Joumals Published on the Internet. Public-Access Computer Systems Review, v7 n4 p5-15.

Describes the development of an electronic journal collection placed on the Internet by the Committee on Institutional Cooperation. Topics include publisher approval, archiving and preservation, World Wide Web home page design, cataloging standardization, and staffing. Concludes with a discussion on the future of the resource and the responsibilities of electronic materials management.

\section{EJ 521772}

James, Frank (1996, January). Electronic Publication-Does It Count? Interpersonal Computing and Technology, v4 n1 p34-56.

Describes the modemization of the administrative building of the Sacred Heart College Senior School in Adelaide, South Australia. Reviews one professor's personal experiences of writing an article for publication in an electronic journal. Discusses the concept that electronic publishing allows interaction via electronic mail between an author and readers of the author's work.

\section{EJ 519191}

Burbules, Nicholas C.; Bruce, Bertram C. (1995, November) This Is Not a Paper. Educational Researcher, v24 n8 p12-18.

Explores some prospects for electronic publishing in educational research. Advantages and drawbacks of electronic publishing are reviewed. Decisions about electronic publishing are actually debates about views of knowledge, writing, and the nature of the scholarly community. Education may be affected more significantly than other fields by changes in electronic publication. 
EJ 505434

Tenopir, Carol. (1995, Spring). Authors and Readers: The Keys to Success or Failure for Electronic Publishing. Library Trends, v43 n4 p571-91.

The goals of authors and readers must be satisfied in order for electronic publishing to succeed. Requirements include timely and widespread dissemination, low creation and distribution costs, peer review, and feedback. The goals of communication, collaboration, interactive publication, and quality can be met with e-mail, listservs, bulletin boards, review copies, and refereed journals.

\section{EJ 516687}

Tompkins, Philip. (1995). Homesteading on the Outskirts of the Gutenberg Galaxy. Community \& Junior College Libraries, v8 nl p87-92.

Examines ways in which the Internet and other electronic publishing media have changed the intellectual, academic, and social geography. Describes the possibilities of these new methods for organizing information to create new outlets for intellectual, artistic, and educational pursuits; conceptions of libraries; and avenues of communication.

\section{EJ 510428}

McAdams, Melinda. (1995, July). Inventing an Online Newspaper. Interpersonal Computing and Technology, v3 n3 p64-90.

Summarizes the issues, debates, and decisions that helped to shape "The Washington Post's" online service, Digital Ink. Highlights include: differences between online and print versions of the newspaper, structure of the user interface, organization of information, content, searching and navigation, and advertising.
EJ 505441

Brichford, Maynard; Maher, William. (1995, Spring). Archival Issues in Network Electronic Publications. Library Trends, v43 n4 p701-711.

Addresses issues of electronic publishing from an archival perspective, including authentication, mutability, reformatting, preservation, editorial and administrative policies, costs, the role of librarians and archivists, technical procedures, access and the rights of privacy and freedom of information, and standards.

\section{EJ 505433}

Bishop, Ann Peterson. (1995, Spring). Scholarly Journals on the Net: A Reader's Assessment. Library Trends, v43 n4 p544570.

Assesses the ease of use and usefulness of network journals through a review of content, format, and policies of seven scholarly journals published primarily on the Internet. Discusses problems, advantages over print journals, and requirements for future scholarly network joumals based on current technology, industry trends, and interviews with faculty and students.

\section{How to Obtain Materials Cited in this Bibliography:}

Journal article citations are from Current Index to Journals in Education. The articles may be obtained from a college, university, or large public library, borrowed through interlibrary loan, or if so indicated, ordered from: UMI Clearinghouse, 300 N. Zeeb Road, Ann Arbor, MI 48106. Phone: 1-800-521-0600.

This column was prepared by the staff of the ERIC Clearinghouse on Information \& Technology, Syracuse University, Syracuse, NY 13244-4100; (315) 443-3640; (800) 464-9107; eric@ericir.syr.edu

\section{News from ERIC}

\section{New Website for ERIC Clearinghouse on Information \& Technology http://ericir.syr.edu/ithome}

Visit ERIC/IT's new World Wide Web site and explore a world of resources in the areas of educational technology and library and information science. You will find ERIC/IT Digests in full text, and you will be able to search the ERIC database via ERIC/ IT's new and easy to use PLWeb search interface. We hope you will find your joumey through these web pages an adventure in information. Set your URL to http://ericir.syr.edu/ithome
Then select the following:

- Welcome: Welcome to ERIC/IT! Click here, and find out more about us: who we are; what we do; how to contact us; and even see a picture of our home.

- Database: Search ERIC, the world's largest educational database. Discover how to order ERIC documents and journal articles, and how to submit your own work to ERIC.

- Publications: Here you will find descriptions of ERIC/IT publications and products. You will find out how to order 
ERIC/IT monographs, Digests, Networkers, minibibliographies and the ERIC video. You can also read our semi-annual newsletter, ERIC/IT Update.

- Digests: ERIC/IT Digests provide brief overviews of topics of current interest, and references for further reading in the fields of library and information science and educational technology. You will be able to read ERIC/IT Digests in full text.

- Library and Information Science: Key associations in library and information science are listed here including their names, addresses, and links to their web pages. You will also find the titles of many frequently read library and information science journals, including subscription addresses. Check out some interesting library and information science resources.

- Educational Technology: Associations specializing in educational technology are highlighted here. Browse the titles and addresses of frequently read educational technology joumals. Link to the web pages of organizations specializing in technology planning, and to full text articles and reports on technology and education reform.

- New: ERIC/TT is constantly growing and changing. Click here to find out about the latest products and projects at ERIC/IT.

- Links: Link to a wealth of sites covering library and information science, educational technology, and K-12 education and the Internet. Find out about the ERIC system and ERIC Clearinghouses all over the United States.

- Communities: Electronic or virtual communities, commonly referred to as listservs, allow people with common interests to share success stories or concems and receive feedback from fellow members. ERIC/IT archives several listservs. Here you can link to the archives of LM_Net, Big Six, and Edtech.

- AskERIC: Connect to "AskERIC: Education Information with the Personal Touch." This award winning education web site began right here at ERIC/TT. Explore the AskERIC Virtual Library, and if you have an education question, you can "AskERIC" right from the home page.

\section{Gateway to Educational Materials}

The National Library of Education(NLE)Advisory Task Force identified lesson plans and teacher guides as top priority area in which NLE should apply library and information science expertise. NLE's goal is to improve the organization and accessibility of the substantial, but uncataloged, collections of such material which are already available on various federal, state, university, non-profit, and commercial Intemet sites. In association with NLE and the U.S. Department of Education,
ERIC/IT at Syracuse University has agreed to spearhead a one year project to provide an operational framework to provide the nation's teachers with "one-stop" access to these Internet lesson plans. According to Michael B. Eisenberg, director of ERIC/IT, "This project's goal is to provide a new set of tools to get information into the hands of educators quickly and easily so that children can leam."

\section{Project Goals}

There are thousands of lesson plans and other curriculum units in web and gopher sites across the Internet. In general, these valuable resources are difficult for most teachers to find in an efficient, effective manner. The goal of the Gateway to Educational Materials (GEM) project is to solve this resource discovery problem.

At the completion of the project in September / October of 1997, a teacher will be able to do the following:

- From any computer capable of browsing the Internet, he or she will be able to access the lesson plans in the digital libraries of the participating sites through the ILPC catalog.

- The teacher will access the ILPC catalog by first navigating to one of the Internet sites participating in the project - the "host" site. It won't matter which of the participating sites the teacher selects. The ILPC will make available the resources of both the host site and the other participating sites.

- At the host site, the teacher will be able to browse through the IIPC catalog of lesson plans using well designed W3 pages or search the contents of the catalog by using a web search engine.

- Using either a search or browse method for locating useful lesson plans, the teacher can then go to the home site of the plan to retrieve it by simply clicking on a link.

- To find lesson plans appropriate to the teacher's task, the catalog will provide a number of "access points." For example, in addition to topic, subject and grade or age ranges, the catalog will make it possible for the teacher to find lesson plans through links to state and national curriculum standards. Part of the work of the project staff and participants (stakeholders and users) will be to determine the optimal profile or set of attributes that should be present in the catalog data and made available to the teacher for purposes of searching and browsing.

\section{Project Issues}

To achieve the goals of the project, there are a number of issues that will be addressed. These issues appear to cluster around five broad topics: 
1. Metadata Profile: The establishment of a metadata profile for lesson plans on the Internet that will support user needs;

2. Metadata Representation: The establishment of a "syntax" or representation scheme for that metadata; and

3. Access Technologies: The identification of candidate technologies that will meet existing circumstances and yet provide a migration path to more powerful retrieval states.

4. Curriculum Standards: The mapping of the lesson plans to state and national curriculum standards.

5. Quality Indicators: The development of some scheme for identifying levels of quality at the level of the individual lesson plan.

More information on the GEM project can be found at the GEM website: http:/ericir.syr.edu/ ilp

\section{Looking for Internet Resources?}

Need information on "Writing Across the Curriculum," "School to Work" or "Technology Plans for School Library Media Centers?" Resources on these and over 120 other topics can be found in AskERIC InfoGuides. AskERIC InfoGuides are the educators' guide to Intemet and ERIC resources. Topics for AskERIC InfoGuides are chosen from frequently asked questions received by AskERIC's award winning question and answer service. Check out AskERIC InfoGuides by visiting the AskERIC WWW site:

$$
\begin{aligned}
& \text { http://ericir.syr.edu } \\
& \text { Select Virtual Library } \\
& \text { Select AskERIC InfoGuides }
\end{aligned}
$$

\section{Recent ERIC Publications}

(Items may be ordered from the address listed below)

Helping With Homework: A Parent's Guide to Information Problem Solving. by Michael B. Eisenberg and Robert E. Berkowitz.

This handbook shows parents a tested approach for helping children of all ages learn and achieve in an information society. By applying the Big Six Skills for information problem-solving model, parents can help students fully understand and successfully complete homework and other school tasks. Eisenberg and Berkowitz apply the Big Six model to sample assignments in language arts, science, math, social studies, as well as to real life situations. The authors also discuss the benefits of using computer software and hardware, the Internet, and other educational technology tools as part of the information problemsolving process.

IR-102; 182 pp., 6" x 9"; $\$ 20.00$ plus $\$ 3.00$ shipping.

(ISBN: 0-937597-42-2)
The Bread \& Butter of the Internet: A Primer and Presentation Packet for Educators

Virtual Dave Lankes

Written for educators, this book provides simple explanations for using Internet resources like e-mail, listservs, telnet, FTP, gopher and the World Wide Web. Internet addresses are provided for many popular professional educational resources. This book also features a teacher training presentation packet, complete with 45 overhead transparency masters and presentation notes. You can use this book and presentation packet to bring others up to speed on Internet technology too.

IR-101; 173 pp. 11 "x $8.5 "$ "; $\$ 20.00$ plus $\$ 3.00$ shipping. (ISBN: 0-937597-41-4)

\section{Trends in Educational Technology 1995}

Donald P. Ely

Identifies and discusses eight current trends in this growing field:

- Computers in schools

- Educational technology in the community

- Networking

- New delivery systems for educational tecbnology

- Television in the school

- Technological literacy for teachers

- Advocacy for educational technology

- Educational technology for educational reform

This content analysis of nearly 1,200 joumals, dissertations, conferences, and ERIC documents identifies current trends in educational technology. IR-99; 79 pp., 6"x9"; $\$ 10.00$ plus $\$ 3.00$ shipping. (ISBN: 0-937597-40-6)

\section{Subscribe to the ITPUBS Listserv}

Subscribe to the ITPUBS listserv and learn about ERIC/IT publications the moment they are released. ITPUBS subscribers will also be the first to hear about limited time offers and special book sales. When you subscribe to ITPUBS, you will be sure to know about the latest information ERIC/IT publishes in the fields of library and information science and educational technology. Subscribing to ITPUBS is easy:

1. Open an e-mail message.

2. Address it to listserv@listserv.syr.edu

3. Leave the subject line blank.

4. In the body, write: subscribe ITPUBS [your first name][your last name].

5. Send the message.

This column was prepared by the staff of the ERIC Clearinghouse on Information \& Technology, Syracuse University, Syracuse, NY 13244-4100; (315) 443-3640; (800) 464-9107; eric@ericir.syr.edu 